Caine DJ, Maffulli N (eds): Epidemiology of Pediatric Sports Injuries.

Individual Sports. Med Sport Sci. Basel, Karger, 2005, vol 48, pp 18-58

\title{
Gymnastics Injuries
}

\author{
Dennis Caine ${ }^{\mathrm{a}}$, Larry Nassar \\ ${ }^{a}$ Department of Physical Education, Health and Recreation, Western \\ Washington University, Bellingham, Wash., and ${ }^{\mathrm{b} C o l l e g e}$ of Osteopathic \\ Medicine, Department of Radiology, Division of Sports Medicine, \\ Michigan State University, Lansing, Mich., USA
}

\begin{abstract}
Objective: The purpose of this chapter is to review the distribution and determinants of injury rates as reported in the pediatric gymnastics injury literature, and to suggest measures for the prevention of injury and directions for further research. Data sources: An extensive search of Pubmed was conducted using the Text and MeSH words 'gymnastics' and 'injury' and limited to the pediatric population ( $0-18$ years). The review focused on studies using denominator-based designs and on those published in the English language. Additional references were obtained from hand searches of the reference lists. Unpublished injury data from the USA Gymnastics National Women's Artistic Gymnastics Championships during 2002-04 were also analyzed. Main results: Comparison of study results was compromised due to the diversity of study populations, variability of injury definition across studies, and changes in rules and equipment across years. Notwithstanding, this review of the literature reveals a reasonably consistent picture of pediatric gymnastics injuries. The incidence and severity of injuries is relatively high, particularly among advanced level female gymnasts. Body parts particularly affected by injury vary by gender and include the ankle, knee, wrist, elbow, lower back, and shoulder. Ankle sprains are a particular concern. Overuse and nonspecific pain conditions, particularly the wrist and low back, occur frequently among advanced-level female gymnasts. Factors associated with an increased injury risk among female gymnasts include greater body size and body fat, periods of rapid growth, and increased life stress. Conclusions: Above all, this overview of the gymnastics injury literature underscores the need to establish large-scale injury surveillance systems designed to provide current and reliable data on injury trends in both boys and girls gymnastics, and to be used as a basis for analyzing injury risk factors and identifying dependable injury preventive measures.
\end{abstract}

Copyright (C) 2005 S. Karger AG, Basel

\section{Introduction}

Gymnastics has enjoyed resurgence in participation and a rise in spectator popularity in recent decades largely due to an increased emphasis on girls' 
sports, the inherent athleticism of gymnastics, and some important personalities who captured the public attention via astonishing performances in competition [1]. Associated with this increased participation is an earlier age of entry and specialization in the sport. Elite female and male gymnasts may initiate training for their sport as early as ages 6 and 9 years, respectively, with peak performance being 10 or more years away. During this period, the degree of difficulty of maneuvers practiced and performed, and the volume and intensity of training increases dramatically.

The increased participation in gymnastics is encouraging because physical activity clearly provides many health-related benefits to those who participate. However, the increased involvement and difficulty of skills practiced at an early age and continued through the years of growth, with the volume or intensity of training required to be competitive, gives rise to concern about the risk and severity and long-term effects of injury to the young gymnast. Indeed, most gymnasts do not pass through their years of training and competition without incurring injury [2].

The purpose of this chapter is to review integratively and comprehensively the distribution and determinants of injury rates as reported in the pediatric gymnastics injury literature, and to suggest measures for the prevention of injury and directions for further research. Data collection focused on the English literature; however, foreign publications that have been translated were also included. Data collection was limited primarily to published articles and reports and was conducted using Pubmed (keywords = gymnastics and injury). Relevant articles cited in the literature retrieved were also located (i.e., ancestry approach). In addition, unpublished data collected at the USA Gymnastics National Women's Artistic Gymnastics Championships during 2002-04 were also included to provide a more complete picture, given the relative paucity of published literature on injuries affecting national-level competitors.

Our search was limited to denominator-based designs including crosssectional, retrospective, and prospective studies. The gymnastics injury literature is replete with epidemiological data, yet too few studies have focused on the pediatric population of gymnasts, especially male gymnasts. Additionally, most of the studies are descriptive in nature and few have sought to analyze risk factors or injury prevention measures [2]. Furthermore, the following methodological shortcomings among the cohort studies restricted the potential to interpret and compare their findings through a common statistical treatment:

- diversity of study populations;

- instability of study results due to relatively short periods of data collection in some studies;

- insufficient sample size to warrant risk factor analysis in some studies;

- low response rates, short- and long-term recall bias, and response motivation bias associated with the frequent use of questionnaires; 
- nonrandom selection or convenience samples (i.e., the possibility that some schools or clubs most concerned with safety may be the ones to consent to involvement in an epidemiological study of injuries); and

- variability in injury definition across studies.

In addition to these methodological shortcomings, comparison of results across studies and years may be further complicated by changes in rules and equipment. Every 4 years, for example, rules are changed that affect the way judges score gymnasts, the way coaches train gymnasts, and the way gymnasts prepare their minds and bodies. Additionally, women's artistic gymnastics frequently changes its equipment to increase the difficulty of skills that a gymnast can perform and to decrease the forces on the body. The use of resi-mats, square foam pits and shredded loose foam pits, for example, have helped to decrease the physical stress on the gymnasts landing their skills. Changes in equipment and rules may lead to different injury patterns and risk of injury.

\section{Incidence of Injury}

\section{Participation Level}

A comparison of injury rates reported in prospective and retrospective injury studies is shown in table 1. Study samples include both female and male recreational [3-5], club [3-18], and high school gymnasts [6, 19]. Overall, there were seventeen studies reporting on injuries affecting female gymnasts and six studies on male gymnasts. Review of table 1 indicates that most injury rates were calculated with reference to participant-seasons and therefore do not account for individual differences in exposure to injury risk. A meaningful comparison across these studies, both within and between genders, is, therefore, difficult.

As shown in table 1, exposure-based injury rates (i.e., number of injuries/ $1,000 \mathrm{~h}$ ) for club-level female gymnasts reported in studies using the same definition of injury (i.e., any damaged body part that would interfere with training) range from 1.4 to 3.7 injuries per $1,000 \mathrm{~h}[9-13,15,17]$. Only one study reported an injury rate relative to the number of athletic-exposures. Caine et al. [13] reported a rate of 8.5 injuries per 1,000 athletic-exposures, which notably is quite similar to that reported for female collegiate gymnasts in the USA [20].

\section{Injury Characteristics}

\section{Injury Onset}

A percentage comparison of injury onset in girls gymnastics is shown in table $2[3,4,7,9-14,16,17,21,22]$. A review of these data indicate that the 
Table 1. A comparison of injury rates in girls' and boys' gymnastics (adapted from Caine [2] and Caine et al. [27])

\begin{tabular}{|c|c|c|c|c|c|c|c|c|c|}
\hline Study & $\begin{array}{l}\text { Design } \\
\text { pros/retro } \\
(\mathrm{P} / \mathrm{R})\end{array}$ & $\begin{array}{l}\text { Data collection } \\
\text { interv/question } \\
\text { (I/Q) }\end{array}$ & $\begin{array}{l}\text { Duration } \\
\text { of injury } \\
\text { survival }\end{array}$ & $\begin{array}{l}\text { Number of } \\
\text { injuries }\end{array}$ & $\begin{array}{l}\text { Sample } \\
\text { Number of } \\
\text { participants } \\
\text { (1 participant = } \\
1 \text { gymnast } \\
\text { participating } \\
\text { in one season })\end{array}$ & $\begin{array}{l}\text { Sample } \\
\text { Number } \\
\text { of teams }\end{array}$ & $\begin{array}{l}\text { Rate } \\
\text { Number } \\
\text { of injuries } \\
\text { per } 100 \\
\text { participant } \\
\text { seasons }\end{array}$ & $\begin{array}{l}\text { Rate } \\
\text { Number } \\
\text { of injuries } \\
\text { per } 1,000 \mathrm{~h} \\
\text { of exposure }\end{array}$ & $\begin{array}{l}\text { Rate } \\
\text { Number } \\
\text { of injuries } \\
\text { per } 1,000 \\
\text { athletic } \\
\text { exposures* }\end{array}$ \\
\hline
\end{tabular}

\section{Females}

Recreational

Pettrone and

$\mathrm{P}$

Ricciardelli [3]

Goodway et al. [4]

Lowry and

Q

7 months

2,016

15

1.6

Leveau [5]

Q

1 year

7

5,929

11 months $128 \quad 3,042$

14

0.1

Club

Garrick and

$\mathrm{P}$

Q

Requa [6]

Weiker [7]

Vergouwen [8]

Pettrone and

$\begin{array}{ll}\mathrm{P} & \mathrm{Q} \\ \mathrm{P} & \mathrm{I}\end{array}$

$\begin{array}{lr}1 \text { season } & 16 \\ 9 \text { months } & 95 \\ 3 \text { seasons } & 353 \\ 7 \text { months } & 29 \\ & \\ 1 \text { year } & 147 \\ 1 \text { year } & 93 \\ 3 \text { seasons } & 90 \\ & \\ \text { 1 year } & 41\end{array}$

Ricciardelli [3]

Caine et al. [9]

Goodway et al. [4] $\mathrm{P}$

Lindner and

$\mathrm{P}$
$\mathrm{P}$

Caine [10]

I $\quad 1$ year $\quad 147 \quad 50$

P Q

1 year

46

$\begin{array}{rr} & 840.5 \\ 15 & 5.3\end{array}$




\begin{tabular}{|c|c|c|c|c|c|c|c|c|c|}
\hline Study & $\begin{array}{l}\text { Design } \\
\text { pros/retro } \\
(\mathrm{P} / \mathrm{R})\end{array}$ & $\begin{array}{l}\text { Data collection } \\
\text { interv/question } \\
\text { (I/Q) }\end{array}$ & $\begin{array}{l}\text { Duration } \\
\text { of injury } \\
\text { survival }\end{array}$ & $\begin{array}{l}\text { Number of } \\
\text { injuries }\end{array}$ & $\begin{array}{l}\text { Sample } \\
\text { Number of } \\
\text { participants } \\
\text { (1 participant = } \\
1 \text { gymnast } \\
\text { participating } \\
\text { in one season) }\end{array}$ & $\begin{array}{l}\text { Sample } \\
\text { Number } \\
\text { of teams }\end{array}$ & $\begin{array}{l}\text { Rate } \\
\text { Number } \\
\text { of injuries } \\
\text { per } 100 \\
\text { participant } \\
\text { seasons }\end{array}$ & $\begin{array}{l}\text { Rate } \\
\text { Number } \\
\text { of injuries } \\
\text { per } 1,000 \mathrm{~h} \\
\text { of exposure }\end{array}$ & $\begin{array}{l}\text { Rate } \\
\text { Number } \\
\text { of injuries } \\
\text { per } 1,000 \\
\text { athletic } \\
\text { exposures* }\end{array}$ \\
\hline $\begin{array}{l}\text { Kolt and } \\
\text { Kirby [12] }\end{array}$ & PR & Q & 18 months & 349 & 64 & 17 & 364 & 3.3 & \\
\hline Caine et al. [13] & $P$ & I & 3 years & 192 & $79^{\mathrm{b}}$ & 1 & & 2.5 & 8.5 \\
\hline $\begin{array}{l}\text { Lowry and } \\
\text { Leveau [5] }\end{array}$ & $\mathrm{R}$ & $\mathrm{Q}$ & 11 months & 260 & 370 & 14 & 70.3 & & \\
\hline $\begin{array}{l}\text { Steele and } \\
\text { White [14] }\end{array}$ & $\mathrm{R}$ & Q & 2 seasons & 146 & 268 & 9 & 54.5 & & \\
\hline Backx et al. [15] & $\mathrm{R}$ & $\mathrm{Q}$ & 7 months & & 220 & & & $3.6^{\mathrm{c}}$ & \\
\hline $\begin{array}{l}\text { Dixon and } \\
\text { Fricker [16] }\end{array}$ & $\mathrm{R}$ & I & 10 years & 325 & 162 & 1 & 200 & & \\
\hline $\begin{array}{l}\text { Kolt and } \\
\text { Kirby [17] }\end{array}$ & $\mathrm{R}$ & Q & 1 year & 321 & 162 & 18 & 198 & 2 & \\
\hline $\begin{array}{l}\text { High School } \\
\text { Garrick and } \\
\text { Requa [6] }\end{array}$ & & & & & & & & & \\
\hline $1973-75$ & $\mathrm{P}$ & IQ & 2 seasons & 39 & 98 & & 39.8 & & \\
\hline $1973-74$ & $\mathrm{P}$ & I & $1 \mathrm{st}$ & & & 3 & $56.0^{\mathrm{d}}$ & & \\
\hline $1974-75$ & $\mathrm{P}$ & Q & 2nd & & & 2 & 28 & & \\
\hline $\begin{array}{c}\text { Garrick and } \\
\text { Requa [6] }\end{array}$ & $\mathrm{P}$ & Q & 1 season & 73 & 221 & 12 & 33 & & \\
\hline
\end{tabular}




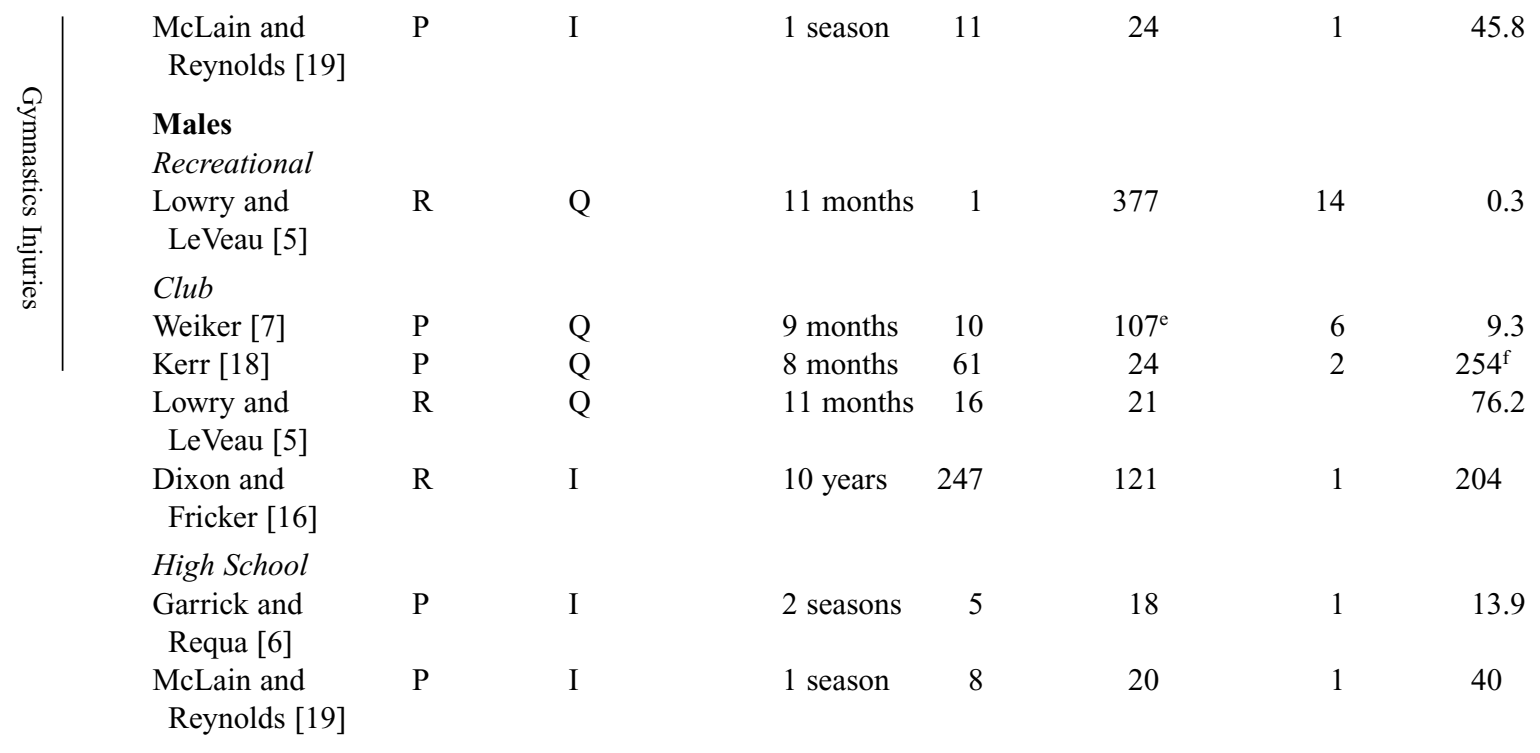

*An athletic exposure (A-E) is one athlete participating in one practice or game in which the athlete is exposed to the possibility of athletic injury. ${ }^{a}$ Including 477 recreational gymnasts.

${ }^{\mathrm{b}}$ Total number of participants during 3 years (mean duration $=17.5$ months).

${ }^{\mathrm{c}}$ Rates include data from 25 male gymnasts.

${ }^{\mathrm{d}}$ This rate was inflated due to high incidence of trampoline injuries; trampoline was eliminated as a scholastic event after this year.

eIncludes 70 recreational gymnasts.

fIncludes data from 8 female gymnasts. 
Table 2. A percent comparison of injury onset in girls' gymnastics (adapted from Caine [2] and Caine et al. [27])

\begin{tabular}{|c|c|c|c|c|c|}
\hline \multirow[t]{2}{*}{ Study } & \multirow{2}{*}{$\begin{array}{l}\text { Study design } \\
\mathrm{P} / \mathrm{R}\end{array}$} & \multirow{2}{*}{$\begin{array}{l}\text { Number of } \\
\text { injuries }\end{array}$} & \multirow{2}{*}{$\begin{array}{l}\text { Number of } \\
\text { participant } \\
\text { seasons* }\end{array}$} & \multicolumn{2}{|c|}{ Injury onset } \\
\hline & & & & Sudden & Gradual \\
\hline \multicolumn{6}{|l|}{ Club } \\
\hline Weiker [7] & $\mathrm{P}$ & 95 & 766 & 42.9 & 57.1 \\
\hline Pettrone and Ricciardelli [3] $]^{* *}$ & $\mathrm{P}$ & 29 & 2,558 & 17.7 & 82.3 \\
\hline Goodway et al. [4] & $\mathrm{P}$ & 93 & 725 & 48 & 52 \\
\hline Caine et al. [9] & $\mathrm{P}$ & 147 & 50 & 55.8 & 44.2 \\
\hline Lindner and Caine [10] & $\mathrm{P}$ & 90 & 362 & 21.9 & 78.1 \\
\hline Bak et al. [11] & $\mathrm{P}$ & 98 & 115 & 39 & 61 \\
\hline Kolt and Kirkby [12] & $\mathrm{P}$ & 349 & & 35.8 & 64.2 \\
\hline Caine et al. [13] & $\mathrm{P}$ & 192 & 159 & 40.6 & 59.4 \\
\hline Steele and White [14] & $\mathrm{R}$ & 146 & 268 & 33 & 67 \\
\hline Dixon and Fricker [16] & $\mathrm{R}$ & 325 & 162 & 36.9 & 63.1 \\
\hline Jones [21] & $\mathrm{R}$ & & & 38 & 62 \\
\hline Mackie and Taunton [22] & $\mathrm{R}$ & 279 & & 44 & 56 \\
\hline Kolt and Kirkby [17] & $\mathrm{R}$ & 321 & 162 & 41.7 & 58.3 \\
\hline
\end{tabular}

*A participant season is one gymnast participating in one season.

**Includes data on recreational gymnasts.

majority of injuries were of sudden onset in nature (range $=52.0-83.4 \%$ ). The pattern of injury onset injuries may vary according to the competitive level. For example, studies of Australian gymnasts [12,17] report that elite gymnasts are characterized by a significantly greater proportion of chronic injuries than subelite gymnasts. In the Eugene study [13], where 82/147 (55.8\%) injuries were gradual onset, gymnasts were highly competitive and trained $20-27 \mathrm{~h}$ weekly.

The pattern of injury onset may also vary by injury location. For example, in one study [13] the majority of wrist and low back injuries were gradual onset while most ankle injuries were sudden onset injuries.

\section{Injury Location}

Identification of commonly injured anatomical sites is important because it alerts sports medicine personnel associated with gymnastics teams to areas in need of special attention. A percentage comparison of injury location reported girls club and high school gymnastics studies is shown in table $3[6,9-14,23$, 24]. A review of the prospective data in this table indicates that the lower extremity was the most frequently injured body region for club-level gymnasts 
Table 3. A percent comparison of injury location in girls' club and high school gymnastics (adapted from Caine [2] and Caine et al. [27])

\begin{tabular}{|c|c|c|c|c|c|c|c|c|c|c|c|c|c|c|}
\hline \multirow[b]{2}{*}{$\begin{array}{l}\text { Number of } \\
\text { injuries }\end{array}$} & \multicolumn{7}{|c|}{ Club: Prospective studies } & \multicolumn{5}{|c|}{ Club: Retrospective studies } & \multicolumn{2}{|c|}{ High School studies } \\
\hline & $\begin{array}{l}\text { Garrick } \\
{[6]} \\
16\end{array}$ & $\begin{array}{l}\text { Weiker } \\
{[7]} \\
95\end{array}$ & $\begin{array}{l}\text { Caine } \\
{[9]} \\
147\end{array}$ & $\begin{array}{l}\text { Lindner } \\
{[10]} \\
90\end{array}$ & $\begin{array}{l}\text { Bak } \\
{[11]} \\
46\end{array}$ & $\begin{array}{l}\text { Kolt } \\
{[12]} \\
64\end{array}$ & $\begin{array}{l}\text { Caine } \\
{[13]} \\
192\end{array}$ & $\begin{array}{l}\text { Steele } \\
{[14]} \\
146\end{array}$ & $\begin{array}{l}\text { Kerr } \\
{[23]} \\
-\end{array}$ & $\begin{array}{l}\text { Dixon } \\
{[16]} \\
325\end{array}$ & $\begin{array}{l}\text { Kolt } \\
{[17]} \\
321\end{array}$ & $\begin{array}{l}\text { Homer } \\
{[24]} \\
49\end{array}$ & $\begin{array}{l}\text { Garrick } \\
{[6]} \\
\text { (mixed) }\end{array}$ & $\begin{array}{l}\text { Garrick } \\
\text { [6] } \\
\text { (interscholastic) }\end{array}$ \\
\hline $\begin{array}{l}\text { Head } \\
\text { Skull } \\
\text { Face } \\
\text { Teeth }\end{array}$ & 6 & $\begin{array}{l}3.2 \\
2.1 \\
1.1 \\
0\end{array}$ & 0.7 & $\begin{array}{l}4.1 \\
1 \\
2.1 \\
1\end{array}$ & 2.4 & 1.1 & 1.6 & 1.4 & & 1.5 & 0.6 & $\begin{array}{l}2 \\
2\end{array}$ & 3 & 7.7 \\
\hline $\begin{array}{l}\text { Spine/Trunk } \\
\text { Neck } \\
\text { Upper back } \\
\text { Lower back } \\
\text { Ribs } \\
\text { Stomach }\end{array}$ & $\begin{array}{l}0 \\
0 \\
0 \\
0 \\
0 \\
0\end{array}$ & $\begin{array}{l}7.5 \\
1.1 \\
0 \\
6.4 \\
0 \\
0\end{array}$ & $\begin{array}{r}15 \\
0.7 \\
0.7 \\
12.2 \\
0.7 \\
0.7\end{array}$ & $\begin{array}{r}16.7 \\
6.3 \\
3.1 \\
5.2 \\
2.1 \\
0\end{array}$ & 9.8 & 17.2 & $\begin{array}{c}19.2 \\
4.2 \\
1 \\
13.5 \\
0.5\end{array}$ & $\begin{array}{c}13.7 \\
2.7 \\
0 \\
11 \\
0\end{array}$ & 0 & $\begin{array}{r}22.3 \\
3.9 \\
2.4 \\
13.3 \\
2.1\end{array}$ & 17.8 & $\begin{array}{r}24.4 \\
4.1 \\
\\
20.3\end{array}$ & 0.6 & 43.6 \\
\hline $\begin{array}{l}\text { Upper extremity } \\
\text { Shoulder } \\
\text { Arm } \\
\text { Elbow } \\
\text { Forearm } \\
\text { Wrist } \\
\text { Hand/Fingers }\end{array}$ & 25 & $\begin{array}{l}18.1 \\
1.1 \\
0 \\
5.3 \\
1.1 \\
6.4 \\
4.2\end{array}$ & $\begin{array}{r}20.5 \\
0.7 \\
0.7 \\
4.8 \\
0.7 \\
9.5 \\
4.1\end{array}$ & $\begin{array}{c}22.9 \\
4.2 \\
1 \\
7.3 \\
0 \\
5.2 \\
5.2\end{array}$ & 17.1 & 20.9 & $\begin{array}{r}21.4 \\
4.2 \\
0.5 \\
3.7 \\
1 \\
9.4 \\
2.6\end{array}$ & $\begin{array}{l}14.4 \\
0 \\
0.7 \\
4.8 \\
0 \\
7.5 \\
1.4\end{array}$ & & $\begin{array}{l}21.7 \\
1.2 \\
0 \\
8.5 \\
0.6 \\
6 \\
5.4\end{array}$ & 22.7 & $\begin{array}{c} \\
4.1 \\
2 \\
10.2 \\
2\end{array}$ & 36 & 12.8 \\
\hline $\begin{array}{l}\text { Lower extremity } \\
\text { Pelvis, hips } \\
\text { Thigh }\end{array}$ & 69 & $\begin{array}{r}70.2 \\
2.1 \\
1.1\end{array}$ & $\begin{array}{r}63.7 \\
2.7 \\
8.7\end{array}$ & $\begin{array}{c}54.1 \\
1 \\
1\end{array}$ & 61 & 59 & $\begin{array}{r}57.8 \\
2.1 \\
4.2\end{array}$ & $\begin{array}{r}69.1 \\
1.3 \\
1.3\end{array}$ & & $\begin{array}{c}55.3 \\
4.5 \\
3\end{array}$ & 57.3 & $\begin{array}{c}54.9 \\
6.1 \\
2\end{array}$ & 48 & 35.9 \\
\hline $\begin{array}{l}\text { Knee } \\
\text { Leg }\end{array}$ & 19 & $\begin{array}{r}24.5 \\
8.5\end{array}$ & $\begin{array}{r}14.3 \\
6.8\end{array}$ & $\begin{array}{c}19.8 \\
0\end{array}$ & & & $\begin{array}{r}10.9 \\
5.2\end{array}$ & $\begin{array}{r}18.5 \\
7.5\end{array}$ & 15 & $\begin{array}{r}10.9 \\
1.5\end{array}$ & & 12.2 & 7 & 5.1 \\
\hline $\begin{array}{l}\text { Ankle } \\
\text { Heel/Achilles } \\
\text { Foot/Toes }\end{array}$ & 25 & $\begin{array}{r}19.1 \\
4.2 \\
10.6\end{array}$ & $\begin{array}{r}21.1 \\
5.4 \\
4.7\end{array}$ & $\begin{array}{r}20.8 \\
4.2 \\
7.3\end{array}$ & & & $\begin{array}{l}12 \\
10.9 \\
12.5\end{array}$ & $\begin{array}{c}22 \\
0 \\
18.5\end{array}$ & $\begin{array}{l}29 \\
12\end{array}$ & $\begin{array}{r}16 \\
6.9 \\
11.5\end{array}$ & & $\begin{array}{l}16.3 \\
18.3\end{array}$ & 10 & 10.3 \\
\hline
\end{tabular}


(range $=54.1-70.2 \%)$ followed by the upper extremity (range $=17.1-25 \%)$, and spine/trunk (range $=0-43.6 \%$ ). The retrospective data suggest a similar injury distribution except that injuries appear somewhat evenly distributed among the spine/trunk (range $=13.7-24.4 \%$ ) and upper extremity (range $=$ 14.4-22.7\%) regions. The most frequently injured body part in the spine/trunk was the lower back in both prospective and retrospective studies. Common injury locations in the upper extremity were the wrist, elbow and hand/fingers. The ankle was typically the most often injured body part in the lower extremity followed by the knee.

Three prospective $[7,18,25]$ and one retrospective [16] study report injury location data on young male gymnasts. In these studies the upper and lower extremities were injured most often, followed by the spine/trunk and head. However, only two of these studies provide complete data [16, 25]. The proportion of injuries affecting the upper (range $=36.4-53.4 \%$ ) and lower (range $=32.8-$ $43.1 \%$ ) extremities was quite similar. In the most extensive and well-documented study of male gymnasts [16], the proportion of upper extremity injuries (53.4\%) was greater than the proportion of lower extremity (32.8\%) injuries.

In all of the studies of young male gymnasts, the shoulder was injured most often (range $=16.8-19 \%)$ followed by the wrist (range $=8.4-13.8 \%$ ) and ankle (range $=9.7-13.9 \%$ ). These findings differ from those of girls' gymnastics and may reflect the different types of apparatus used in men's gymnastics that place greater physical demands on the upper body.

\section{Situational}

Injury Rates in Practice versus Competition

It is not surprising that more injuries occur during practice than competition since more time is spent training than competing. In girls' gymnastics studies $[3,6,9-11,13,23]$ the percentage of all injuries that occur in practice varies from 79 to $96.6 \%$. In contrast, the proportion of injuries occurring in competition varies from 3.4 to $21 \%$ [3, 6, 9-11, 13, 23]. However, when the number of injuries is computed with reference to exposure data, injury rates are greater during competition than training for (7.4 vs. 2.4 injuries/1,000 h) [9]. This finding may be explained by the fact that gymnasts are better protected in training than in competition because of landing in foam pits, spotting, and softer mats [26]. Nerves and time pressures may also be contributing factors.

Unpublished data on injuries sustained by competitors at the 2002, 2003, and 2004 USA Gymnastics National Women's Artistic Gymnastics Championships are summarized in table 4. Definition of injury was any gymnastics-related condition that required treatment by the USAG Medical Staff. These included both acute and overuse conditions. Perusal of table 4 reveals that $27.6-80 \%$ of the junior and from 62.5 to $70 \%$ of senior gymnasts, respectively, were treated for 
Table 4. Injuries treated at the 2002-04 USA Gymnastics National Women's Artistic Gymnastics Championships

\begin{tabular}{|c|c|c|c|c|c|c|c|c|}
\hline Diagnosis & $\begin{array}{l}2002 \\
\text { Junior }\end{array}$ & $\begin{array}{l}2002 \\
\text { Senior }\end{array}$ & $\begin{array}{l}2003 \\
\text { Junior }\end{array}$ & $\begin{array}{l}2003 \\
\text { Senior }\end{array}$ & $\begin{array}{l}2004 \\
\text { Junior }\end{array}$ & $\begin{array}{l}2004 \\
\text { Senior }\end{array}$ & Total & Per cent \\
\hline Apophysitis & & & & & & & {$[5]$} & $3.4 \%$ \\
\hline $\begin{array}{l}\text { Osgood-Schlatter } \\
\text { disease }\end{array}$ & & & 1 & & 2 & & 3 & \\
\hline Sever's disease & & 1 & 1 & & & & 2 & \\
\hline Contusion & & & & & & & {$[5]$} & $3.4 \%$ \\
\hline Calcaneous & & & & & & 1 & 1 & \\
\hline Foot & & & 1 & & & & 1 & \\
\hline Iliotibial band & & & & 1 & & & 1 & \\
\hline Metatarsal & & & 1 & & & & 1 & \\
\hline Toes & & & 1 & & & & 1 & \\
\hline Dislocation & & & & & & & [1] & $0.7 \%$ \\
\hline Elbow & & 1 & & & & & 1 & \\
\hline Fracture & & & & & & & [13] & $8.9 \%$ \\
\hline Fibula (stress fracture) & & 1 & & & & & 1 & \\
\hline $\begin{array}{l}\text { Ischial tuberosity } \\
\text { (avulsion) }\end{array}$ & & 1 & & & & & 1 & \\
\hline Metacarpal & & & & 1 & 1 & & 2 & \\
\hline $\begin{array}{l}\text { Metatarsal (stress } \\
\text { reaction) }\end{array}$ & & 1 & & & & & 1 & \\
\hline Phalanx & & 1 & & & & & 1 & \\
\hline Phalanx (Salter-Harris III) & & & & & & 1 & 1 & \\
\hline Spondylolysis & & 1 & & 1 & & & 2 & \\
\hline Talus & & 1 & 1 & & & 1 & 3 & \\
\hline Tibia tubercle (avulsion) & & & 1 & & & & 1 & \\
\hline
\end{tabular}


Table 4 (continued)

Diagnosis

2002

2003

2004

2004

Total

Per cent

Impingement

Senior Junior Senior

Ankle

Shoulder

Laceration/Rip

Hand

Toes

Muscle Spasm/Tightness

Calf

Gluteus

Quadriceps

Paraspinal

Nonspecific pain

Low back

Lumbar facet

syndrome

Thoracic myalgia

Osteochondritis

dessicans

Knee

Overuse (Muscle/Tendon)

Achilles tendonitis

Bursitis

Costochondritis

Epicondylitis (elbow)

$\begin{array}{ll} & \\ & \\ 2 & \\ 2 & \\ & \\ & \\ & \\ 1 & \\ 1 & \\ & \\ & \end{array}$

1

1

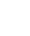

3

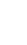

1

1

3

1

[2]

$1.4 \%$

1

1

[5] $\quad 3.4 \%$

1

4

$\begin{array}{ll}1 & 2 \\ 1 & 1\end{array}$

[26]

$\begin{array}{ll}2 & 4 \\ 1 & 1\end{array}$

1
[8]

2

3

2

[21]

18

1

[2]

2

[26] $\quad 17.8 \%$

$[26]$
4

$5.5 \%$

$14.4 \%$

1

1
1


Medial tibial stress

syndrome

Patellar tendonitis

Planter fascitis

1

Rotator cuff tendonitis

Sesamoiditis

Respiratory problem

Infection

Pharyngitis

Sprain (ligament)

Ankle

Cervical

Elbow

Foot

Knee

Sacroiliac joint

Wrist

Strain

(Muscle/Tendon)

Achilles

Adductor

Forearm

Groin

Hamstring

Hip flexor

Quadriceps

Torn cartilage

Medial knee meniscus

2
3

2]

1

5

5

1

2

1

1

2

1

1

3

2

1

$12]$

$8.2 \%$

$\begin{array}{lll} & 1 \\ 1 & 1 \\ & 1 \\ 1 & 1 \\ & 4 \\ & 3 \\ & & 1\end{array}$

[3]

3 
Table 4 (continued)

\begin{tabular}{lcccccccc}
\hline Diagnosis & $\begin{array}{l}2002 \\
\text { Junior }\end{array}$ & $\begin{array}{l}2002 \\
\text { Senior }\end{array}$ & $\begin{array}{l}2003 \\
\text { Junior }\end{array}$ & $\begin{array}{l}2003 \\
\text { Senior }\end{array}$ & $\begin{array}{l}2004 \\
\text { Junior }\end{array}$ & $\begin{array}{l}2004 \\
\text { Senior }\end{array}$ & Total & Per cent \\
\hline $\begin{array}{l}\text { Torn tendon } \\
\text { Achilles }\end{array}$ & & & & & & 1 & 1 \\
Total number of injuries & & & & & & 1 & $0.7 \%$ \\
Total number of participants & 29 & 20 & 31 & 32 & 15 & 39 & 146 & \\
Number of injuries/100 participants & 31 & 100 & 125 & 28 & 20 & 35 & \\
Total number of injured gymnasts & 8 & 14 & 18 & 20 & 114.3 & 27 & \\
Percent of injured gymnasts & $27.6 \%$ & $70 \%$ & $72.0 \%$ & $62.5 \%$ & $80 \%$ & $69.2 \%$ & \\
\hline
\end{tabular}


injuries at the various championships. The most common injury types were sprains (27.4\%), overuse conditions (17.8\%), and nonspecific pain (14.4\%). The most common injury locations were the ankle (16.4\%), low back (12.3\%), and lower leg $(7.5 \%)$. Overall, 16 injuries $(11 \%)$ required surgery. The most common surgeries were for fracture repair $(\mathrm{n}=4)$, anterior cruciate ligament reconstruction $(\mathrm{n}=3)$, and meniscus repair $(\mathrm{n}=3)$. Injury rates ranged from 31 to 124 injuries per 100 participants.

\section{Action or Activity}

Most reported data on events associated with injury in girls' gymnastics are flawed because they include both sudden and gradual onset injuries [27]. That is, it is difficult to determine whether gradual onset injuries are specifically related to maneuvers in a given event. Additionally, most injury data on events are expressed as percentage values, which do not account for differential gymnast exposures among the various gymnastics events [27]. One study which reports exposure-based acute injury rates for events in girls' gymnastics indicates that floor exercise is the event with the highest injury rate among clublevel female gymnasts [9]. Notably, floor exercise also had the highest frequency of injury during the international competitions between 1983 and 1998 [28].

Only one study reported events associated with injury in boys' gymnastics. Lueken et al. [25] reported 345 injuries affecting club level gymnasts attending the U.S. Olympic Training Center over a 15 -year period. Floor exercise was most often associated with injury (24.9\%), followed by still rings (19.2\%), horizontal bar $(16.9 \%)$, parallel bars (16.4\%), pommel horse (14.7\%), and vault $(7.9 \%)$.

\section{Chronometry}

Time of practice

Three studies $[9,10,13]$ report a relatively high frequency of injuries occurring early in practice, suggesting the possibility of a qualitatively or quantitatively insufficient warmup for the gymnasts studied. Other possible explanations include the possibility that appropriate progressions were not provided and that gymnasts may practice difficult skills earlier in practice when they are most fresh. Of note, one study [9] reported that 7 of 12 acute competition injuries occurred during the first half-hour of competition, which was during the timed warmup.

\section{Time of Season}

Several injury studies report the time of season when injury occurs in girls' gymnastics $[9,13,16,23]$. These studies report a relative increase in injury rates: - Following periods of reduced training such as a short vacation or recuperation $[9,13]$ - perhaps due to an increased workload demands [26]; 
- During competitive routine preparation [13] - perhaps due to increased fatigue during performance of longer combinations and routines and/or hurried attempts to prepare routines with skills, which are not thoroughly learned [29]; and

- During the weeks just prior to competition $[9,23]$ - perhaps due to a heightened competitive anxiety or stress [23], or performing skills which are not thoroughly learned.

\section{Injury Severity}

Injury severity can span a broad spectrum from abrasions to fractures, to those injuries that result in severe permanent functional disability or even death. In the gymnastics literature, injury severity is usually indicated by one or more of the following: injury type, time loss, surgery, and clinical outcome.

Injury Type

A percentage comparison of injury types sustained by female participants in recreational [5], club [3, 5, 6, 9, 10, 12, 13, 17], and high school [6] gymnastics is shown in table 5. Sprains (range $=15.9-43.6 \%$ ) and/or strains (range $=6.4-31.8 \%$ ) are consistently among the three most common injury types for these gymnasts. Other common injury types include contusions, fractures, and overuse injuries. There were no corresponding data for young male gymnasts.

\section{Lower Back}

As shown in table 3, the low back is typically the most frequently injured body part in the spine/trunk region of female gymnasts. The young gymnast engaging in strenuous training and competition places demands on the lower back unparalleled in most other sports. Demands on the gymnast's back include repetitive flexion and hyperextension postures during vaulting, dismounts, and somersaults. In addition to the hyperlordotic postures, vertical impact loading occurs as the gymnast lands on both feet during dismount activities [30]. It is the chronic repetitive flexion, hyperextension, rotation, and compressive loading of the spine during these activities that may cause injuries to the spinal elements [31, 32]. The spine, as with the rest of the skeleton, is at greater risk of injury during the adolescent growth spurt [33].

Table 6 summarizes radiographical data on specific injuries and conditions involving the lower back of female and male gymnasts [34-45]. Common injury sites reported include the vertebral bodies, intervertebral discs, and pars interarticularis. Common problems reported include back pain, radiographical 
Table 5. A percent comparison of injury types in girls' gymnastics (adapted from Caine [2] and Caine et al. [27])

Level/Study Number of Abrasion Concussion Contusion Dislocation Fracture Inflammation Laceration Nonspecific Sprain Strain Other injuries/

particular

season

Recreational

Retrospective study

Lowry and Leveau [5] 128/3042 $\quad 0$

Club

Prospective studies

Garrick and Requa [6]

Pettrone and

Ricciardelli $[3]^{* *}$

Caine et al. [13]

Lindner and Caine [10]

Kolt and Kirkby [12]

Caine et al. [9]

$128 / 3042$

1.6

$29 / 542$

$147 / 50$

$90 / 36$

$349 /-$

$192 / 159$

0
0
2.2
0
0.5

Retrospective studies

Lowry and Leveau [5]

Kolt and Kirkby [17]

$260 / 370 \quad 0 \quad 0$

High school

Propective study

Garrick and Requa [6]

1 year (mixed study)

2 year (interscholastic

$321 / 162$

study)

4.1

20.5

0

9.7

9.7

4.1

6.5

6

8.9

34.2

3.1

1.6

8.4

$\begin{array}{ll}8.1 & 13.8\end{array}$

15.3

8.2

0 $\begin{array}{lll}39.7 & 31.5 & 16.4\end{array}$

$\begin{array}{lll}43.6 & 17.9 & 17.9\end{array}$

*A participant season is one gymnast participating in one season.

**Includes data for recreational as well as club gymasts. 
Table 6. Cross-sectional studies of lower back conditions affecting young female and male gymnasts (adapted from Caine [2] and Caine et al. [27])

\begin{tabular}{|c|c|c|c|c|}
\hline Study & $\mathrm{n}$ & Age & Level & Condition/Diagnosis \\
\hline Jackson et al. [34] & 100 & 14 & regional & $\begin{array}{l}\text { Bilateral L5 pars interarticularis defects } \\
(11 \%), 6 \text { of the } 11 \text { cases had coexisting } \\
\text { spondylolisthesis at L5 }\end{array}$ \\
\hline Rossi [35] & 132 & & olympic & $32.8 \%$ spondylolysis; $8.9 \%$ spondylolisthesis \\
\hline Ohlen et al. [36] & 64 & 11.9 & club & Low back pain in $20 \%$ of the subjects \\
\hline Sward et al. [37] & 26 & $16-25$ & national & $\begin{array}{l}19.2 \% \text { spondylolysis, } 4 / 5 \text { with existing } \\
\text { spondylolisthesis }\end{array}$ \\
\hline Rossi and Dragoni [38] & 417 & $15-27$ & competition & $16.31 \%$ spondylolysis \\
\hline \multirow[t]{2}{*}{ Tertti et al. [39] } & $17 \mathrm{~F}$ & $8-19$ & $\begin{array}{l}\text { district, } \\
\text { national and } \\
\text { international }\end{array}$ & $\begin{array}{l}\text { Sacrilization of L5 (5.9\%), Scheuermann's } \\
\text { disease }(5.9 \%) \text {, spondylolysis at L5 (5.9\%) }\end{array}$ \\
\hline & $18 \mathrm{M}$ & $8-14$ yrs & $\begin{array}{l}\text { district, } \\
\text { national and } \\
\text { international }\end{array}$ & $\begin{array}{l}\text { Sacrilization of L5 }(11.1 \%) \\
\text { Scheuermann's disease }(11.1 \%) \\
\text { disc degeneratioin }(5.6 \%)\end{array}$ \\
\hline \multirow[t]{3}{*}{ Hellstrom et al. [40] } & $26 \mathrm{~F}$ & $14-25$ & $\begin{array}{l}\text { nationally } \\
\text { ranked }\end{array}$ & $\begin{array}{l}\text { Scoliosis }(11.5 \%) \text {, spondylolysis }(19.2 \%) \\
\text { with coexisting spondylolisthesis in } 4 \text { of the } \\
5 \text { cases, abnormal configuration of the } \\
\text { vertebrae }(15.4 \%) \text {, disk height reduction } \\
(3.8 \%) \text {, Schmorl's nodes }(11.5 \%), \\
\text { apophyseal abnormalities }(15.4 \%)\end{array}$ \\
\hline & $26 \mathrm{M}$ & $16-25$ & national & $\begin{array}{l}\text { Scoliosis }(19.2 \%) \text {, spondylolysis and } \\
\text { spondylolisthesis }(11.5 \%) \text {, abnormal } \\
\text { configuration of the vertebrae }(38.5 \%) \text {, disc } \\
\text { height reduction }(11.5 \%) \text {, Schmorl's nodes } \\
(26.9 \%) \text {, apophyseal abnormalities }(11.5 \%)\end{array}$ \\
\hline & $30 \mathrm{M} / \mathrm{F}$ & $16-25$ & nonathletes & $\begin{array}{l}\text { Scoliosis }(3.3 \%) \text {, spondylolysis }(3.3 \%) \text {, } \\
\text { coexisting spondylolisthesis }(3.3 \%) \text {, spina } \\
\text { bifida occulta }(13.3 \%) \text {, abnormal } \\
\text { configuration of the vertebrae }(10 \%), \\
\text { disk height reduction }(6.7 \%), \\
\text { Schmorl's nodes }(40 \%)\end{array}$ \\
\hline \multirow[t]{2}{*}{ Sward et al. [41] } & $26 \mathrm{~F}$ & $14-25$ & national & $\begin{array}{l}65.4 \% \text { had moderate or severe pain; } \\
42.3 \% \text { radiological abnormalities of the } \\
\text { thoraco-lumbar spine }\end{array}$ \\
\hline & $26 \mathrm{M}$ & $16-25$ & national & $\begin{array}{l}84.6 \% \text { had moderate or severe pain; } \\
42.3 \% \text { radiological abnormalities of the } \\
\text { thoraco-lumbar spine }\end{array}$ \\
\hline \multirow[t]{4}{*}{ Goldstein et al. [42] } & $8 \mathrm{~F}$ & 25.7 & national & Spondylolysis $(12.5 \%)$; abnormal disk $(62.5 \%)$ \\
\hline & $14 \mathrm{~F}$ & 16.6 & elite & Spondylolysis (21.4\%); abnormal disk (21.4\%) \\
\hline & $11 \mathrm{~F}$ & 11.8 & pre-elite & Spondylolysis $(9.1 \%)$; abnormal disk $(0)$ \\
\hline & $11 \mathrm{~F}$ & 18.6 & swimmers & Abnormal disk $(9.1 \%)$ \\
\hline
\end{tabular}


Table 6 (continued)

\begin{tabular}{|c|c|c|c|c|}
\hline Study & $\mathrm{n}$ & Age & Level & Condition/Diagnosis \\
\hline \multirow[t]{2}{*}{ Sward et al. [43] } & $26 \mathrm{~F}$ & $14-25$ & national & $\begin{array}{l}\text { Abnormalities of the anterior aspects of } \\
\text { the vertebral ring apophyses }(30.8 \%)\end{array}$ \\
\hline & $26 \mathrm{M}$ & $16-25$ & national & $\begin{array}{l}\text { Abnormalies of the anterior aspects of } \\
\text { the vertebral ring apophyses }(19.2 \%)\end{array}$ \\
\hline Soler and Calderson [44] & 112 & 14.3 & top-level & Spondylolysis $(17 \%)$ \\
\hline Szot et al. [45] & $52 \mathrm{M}$ & $15-31$ & national & $\begin{array}{l}\text { Radiological changes of the spinal column } \\
(65.8 \%) \text { (i.e., fracture and deformation } \\
\text { of vertebral bodies, degeneration of the } \\
\text { intervertebral discs, degenerative changes } \\
\text { of the intervertebral articulations) }\end{array}$ \\
\hline
\end{tabular}

abnormalities of the vertebral bodies including abnormal configuration (flattening, wedging, and increased sagittal diameter), Schmorl's nodes and apophyseal changes, increased degenerative disc changes, and damage to the pars interarticularis with resultant spondylolysis (prevalence $=5.9-32.8 \%$ ) and spondylolisthesis.

In the past, women's gymnastics focused on extreme reclination of the lumbar spine (e.g., frequent walkovers with extremely extended lumbar spine), which is believed to relate to the relatively high prevalence of spondylolysis in this sport [31]. In contrast, women's gymnastics has recently concentrated on a fixed and well-controlled spinal movement with forward flexed spine during landing, which may result in a decreased risk of spondylolysis $[2,31]$. The repeated trunk flexion when landing from various heights, however, may create biomechanical compression forces sufficient to damage the anterior aspects of the spine. Anterior vertebral fractures and other anterior spine problems are now more common than the posterior problems seen during the era of contortionistic spine positions in poses, walkovers and limbers $[31,33,46-51]$.

\section{Upper Extremity}

Unlike most other sports, in gymnastics, the upper extremities are used as weight-bearing limbs causing high impact loads to be distributed through the elbow and wrist. Considering the upper extremity's ill-adapted design for weight-bearing, it is not surprising that it is the second most frequently injured body region. As shown in table 3 , the wrist is the most frequently injured site in the upper extremity of female gymnasts followed by the elbow. In male gymnasts, the shoulder has been the most frequently injured upper extremity body 
part followed by the wrist. However, wrist injuries and conditions have been the focus of many cross-sectional reports for both male and female gymnasts.

Table 7 briefly summarizes data from cross-sectional studies of injuries and conditions involving the wrist of female and male gymnasts. Wrist pain is a common complaint among gymnasts, with prevalence estimates ranging from 46 to $87.5 \%$ [52-55]. Eight cross-sectional studies [45, 52-60] report prevalence estimates of radiographical abnormalities consistent with distal radius physeal-stress reaction in $10-85 \%$ of gymnasts.

A concern voiced in the literature is that gymnastics training may inhibit radial growth in female gymnasts [61]. Although case studies have established the presence of premature closure of the distal radius among female gymnasts [62-65], there are currently few data which provide prevalence or incidence estimates for this condition. However, in one cross-sectional study of Chinese opera students (training included gymnastics) there were 2 cases (2/77 or $2.6 \%$ ) of early partial closure of the distal radial growth plate [59]. In another study involving 18 top-level Chinese gymnasts, the nature and frequency of growthplate conditions were monitored radiographically over 9 years [66]. During that period, 6/18 (33.3\%) of the girls developed progressive pathology leading to 'hindered radial growth' and a 'relatively lengthened ulna'.

\section{Lower Extremity}

The lower extremity is also a site of tremendous physical loading in gymnastics. This involves the repetitive jarring impact of vault takeoffs and dismounts from a variety of heights and during tumbling activities. A review of the data in table 3 shows that the lower extremity is actually the region most affected by injury in girls' gymnastics. Yet surprisingly, there are no published prevalence data on lower extremity injuries affecting female or male gymnasts. However, two cohort studies report inversion ankle injuries are the most frequent lower extremity injury followed by Sever's disease [16, 22]. Ankle sprains were also the most common injury sustained by gymnasts participating in the USA Gymnastics National Women's Artistic Gymnastics Championships during 2002-04 (see table 4).

\section{Catastrophic Injury}

The worst case scenario in gymnastics is catastrophic injury. The recently publicized spinal cord injuries of national-level gymnasts Sang Lan of China and Julissa Gomez of USA $[67,68]$ focused public attention on the potential for catastrophic injury in gymnastics. The limited incidence data shown in table 8 suggest that catastrophic injury is a relatively infrequent occurrence among high school male and female gymnasts $[69,70]$. However, there is a conspicuous absence of research reporting rate data for catastrophic injuries affecting 
Table 7. Cross-sectional studies of wrist injuries and conditions affecting young female and male gymnasts (adapted from Caine [2] and Caine et al. [27])

\begin{tabular}{|c|c|c|c|c|}
\hline Study & $\mathrm{n}$ & Age & Level & Diagnosis/Condition \\
\hline \multirow[t]{2}{*}{ Auberge et al. [56] } & $57 \mathrm{~F}$ & $14-17$ & $\begin{array}{l}\text { junior } \\
\text { national }\end{array}$ & $\begin{array}{l}\text { Chronic osteoarticular lesions involving the distal radial } \\
\text { growth plate }(85 \%)\end{array}$ \\
\hline & $41 \mathrm{M}$ & $17-33$ & $\begin{array}{l}\text { junior } \\
\text { national }\end{array}$ & $\begin{array}{l}\text { Chronic osteoarticular lesions involving the distal radial } \\
\text { growth plate }(80 \%)\end{array}$ \\
\hline Szot et al. [45] & $41 \mathrm{M}$ & $15-31$ & national & Distal radial epiphyseal irregularities $(58.5 \%)$ \\
\hline Roy et al. [57] & $26 \mathrm{~F}$ & $9-14$ & class II & $\begin{array}{l}\text { Minimal widening and irregularity of the distal radial growth } \\
\text { plate }(30.8 \%)\end{array}$ \\
\hline \multirow[t]{2}{*}{ Caine et al. [52] } & $39 \mathrm{~F}$ & 12.6 & III, II, I & $\begin{array}{l}\text { Minimal widening and irregularities of the distal radial } \\
\text { physis }(10 \%)\end{array}$ \\
\hline & $21 \mathrm{M}$ & 12.6 & IV, III, II, I & $\begin{array}{l}\text { Definite changes of subchondral sclerosis, physeal widening, } \\
\text { marginal new bone formation, and distortion of the distal end } \\
\text { of the radius }(4.8 \%)\end{array}$ \\
\hline DeSmet et al. [58] & $\begin{array}{l}156 \mathrm{~F} \\
\text { (not fused) }\end{array}$ & 15.9 & national & $\begin{array}{l}\text { Enlargement of the distal radial growth plate with irregular } \\
\text { borders in } 10 \% \text { of the cases; at baseline, } 23 \text { of } 50 \text { gymnasts } \\
\text { had wrist pain }\end{array}$ \\
\hline Chang et al. [59] & $\begin{array}{l}176 \mathrm{M} / \mathrm{F} \\
(77 \mathrm{~F}, 99 \mathrm{M})\end{array}$ & $11-16$ & $\begin{array}{l}\text { Chinese } \\
\text { Opera } \\
\text { students }\end{array}$ & $\begin{array}{l}\text { Unfused group: } 10 \text { girls }(14.3 \%) \text { and } 32 \text { boys ( } 32.3 \%) \text { showed } \\
\text { stress-related changes of the distal radial growth plate; } 23 \text { cases } \\
\text { show early partial closure of the distal radial growth plate }\end{array}$ \\
\hline $\begin{array}{l}\text { De Fiori and } \\
\text { Mandelbaum [53] }\end{array}$ & $\begin{array}{l}52 \mathrm{M} / \mathrm{F} \\
(32 \mathrm{~F}, 20 \mathrm{M})\end{array}$ & 11.8 & club level & $\begin{array}{l}38(73 \%) \text { reported wrist pain within the past } 6 \text { months; } \\
\text { gymnasts with wrist pain were older, trained at a higher skill } \\
\text { level, trained more hours per week, and began training at an } \\
\text { older age }\end{array}$ \\
\hline De Fiori et al. [54] & $\begin{array}{l}44 \mathrm{M} / \mathrm{F} \\
(27 \mathrm{~F}, 17 \mathrm{M})\end{array}$ & 11.6 & nonelite & $\begin{array}{l}11 \text { gymnasts }(25 \% \text {; MF) showed radiographical evidence of } \\
\text { stress injury to the distal radial physis }\end{array}$ \\
\hline
\end{tabular}


Table 7 (continued)

\begin{tabular}{|c|c|c|c|c|}
\hline Study & $\mathrm{n}$ & Age & Level & Diagnosis/Condition \\
\hline De Fiori et al. [60] & $\begin{array}{l}47 \mathrm{M} / \mathrm{F} \\
(21 \mathrm{~F}, 26 \mathrm{M})\end{array}$ & $5-16$ yrs & club level & $\begin{array}{l}\text { Wrist pain was reported by } 57 \% \text { ( } 27 \text { of } 47 \text { ) of the gymnasts; } 81 \% \\
\text { ( } 24 \text { of } 27 \text { ) reported wrist pain both at study onset and one year } \\
\text { later; } 42 \% \text { of subjects with wrist pain reported that } \\
\text { symptoms interfered with training }\end{array}$ \\
\hline Di Fiori et al. [ 55] & $\begin{array}{l}59 \mathrm{MF} \\
(28 \mathrm{~F}, 31 \mathrm{M})\end{array}$ & 9.3 & club level & $\begin{array}{l}\text { Wrist pain was reported by } 56 \% \text { ( } 33 \text { of } 59 \text { ) of the gymnasts, } \\
\text { with } 45 \% \text { ( } 15 \text { of } 33 \text { ) describing pain of at least } 6 \text { months; } 51 \% \\
\text { of the gymnasts ( } 30 \text { of } 59 \text { ) had a finding of stress injury to the } \\
\text { distal radial physis of at least a grade } 2\end{array}$ \\
\hline
\end{tabular}


Table 8. A summary of catastrophic injury rates in high school gymnastics (adapted from Caine [2] and Caine et al. [27])

\begin{tabular}{|c|c|c|c|c|c|}
\hline Study & Duration & Injuries & Condition & $\begin{array}{l}\text { Rate*, Number of } \\
\text { cases/injures } \\
\text { per } 100,000 \\
\text { male participants }\end{array}$ & $\begin{array}{l}\text { Rate*, Number of } \\
\text { cases/injuries } \\
\text { per } 100,000 \\
\text { female participants }\end{array}$ \\
\hline Clarke [69] & $\begin{array}{l}3 \text { years } \\
(1973-75)\end{array}$ & $\begin{array}{l}1 \mathrm{~F} \\
1 \mathrm{M}\end{array}$ & $\begin{array}{l}\text { permanent }^{\mathrm{a}} \\
\text { permanent }^{\mathrm{a}}\end{array}$ & & \\
\hline $\begin{array}{l}\text { National Center for } \\
\text { Catastrophic Sports } \\
\text { Injury Research [70] }\end{array}$ & $\begin{array}{l}21 \text { years } \\
(1982-2003)\end{array}$ & $\begin{array}{l}1 \mathrm{M} / \mathrm{F} \\
8 \mathrm{M} / \mathrm{F} \\
4 \mathrm{M} / \mathrm{F}\end{array}$ & $\begin{array}{l}\text { fatal } \\
\text { nonfatal }^{\mathrm{b}} \\
\text { serious }^{\mathrm{c}}\end{array}$ & $\begin{array}{l}1.15 \\
2.3 \\
1.15\end{array}$ & $\begin{array}{l}0 \\
1.1 \\
0.55\end{array}$ \\
\hline
\end{tabular}

${ }^{a}$ Refers to permanent disability, including death, secondary to spinal cord injury.

bermanent, severe functional disability such as quadriplegia.

${ }^{\mathrm{c}}$ No permanent severe functional disability, but severe injury.

club-level gymnasts. This finding is a concern given the escalation of difficulty and combination ratings in gymnastics; also, because the vast majority of competitive gymnasts participate at the club level.

Notably, several recent longitudinal studies of injuries affecting club-level female gymnasts report no catastrophic injuries $[9,10,12,13,16]$. In contrast, a national spinal cord injury registry in Japan revealed 23 spinal cord injuries to competitive gymnasts during 1990-92 [71], and between 1985 and 1997 there were 6 competitive gymnasts with spinal cord injuries treated at the Orthopedic Department at the University of Heidleberg [72].

\section{Time Loss}

A commonly used measure of injury severity is the duration of restriction from training and competition. Time loss due to injury is difficult to measure in gymnastics because injured gymnasts, depending on the severity of injury, tend to continue to train on selected apparatus with some skill or movement modifications. In addition, there are many possible subjective and objective factors that may influence performance time lost due to injury (e.g., personal motivation, peer influence, coaching staff reluctance or encouragement, approaching competition). This bias is minimized when numerical definitions are used [73].

Data from two studies of club-level female gymnasts using the same injury definition $[9,13]$ indicate that advanced-level participants experience a greater proportion of severe ( $>21$ days time loss) injuries than beginning-level girl gymnasts. Similarly, several studies report that mean time loss per injury is greater for advanced- than beginning-level female gymnasts $[9,12,17]$. 


\section{Clinical Outcome}

Re-Injury

A high frequency of re-injury suggests an underestimation of the severity of the primary injury, inadequate rehabilitation, and/or premature return to training or competition [12]. There are few data on percentage or rate of re-injury among female gymnasts. In three cohort studies involving female gymnasts, percentage of injuries that were re-injuries ranged from 24.5 to $32.3 \%[9,10,12]$. Cross-tabulation of re-injury with injury onset in two studies $[9,12]$ suggests that the majority of re-injuries affecting club-level gymnasts are chronic injuries.

\section{Residual Symptoms}

Two studies investigated former top-level female gymnasts for back pain and radiological changes $[74,75]$. Both studies reported no significant differences in back pain between gymnast and control groups; however, the prevalence of radiological abnormalities was greater in gymnasts than controls in one study [74]. Maffuli et al. [76] reported the long-term follow-up (mean = 3.6 years) of lesions of the articular surface of the elbow joint in a group of 12 gymnasts ( 6 females, 6 males). In this group there was a high frequency of osteochondritic lesions, intra-articular loose bodies, and precocious signs of joint aging. Residual mild pain in the elbow at full extension occurring after activity was present in 10 patients, and all patients showed marked loss of elbow extension compared with their first visit.

\section{Nonparticipation}

Several case series studies have reported 'career-ending' injuries affecting the elbow [76-78] and low back [50] of young gymnasts. In a 10-year cohort study of Australian elite gymnasts, 7 females and one male (8/116) retired as a result of injury [16]. In this study, injuries that resulted in retirement included chronic rotator cuff injury, navicular stress fracture, loose bodies in the ankle joint, medial and lateral meniscus lesions, anterior cruciate ligament rupture, and osteochondritis of the elbow joint. In three cohort studies $[9,12,79]$ from 16.3 to $52.4 \%$ of dropouts were injured when they withdrew from participation, thus implicating injury as a likely contributing factor in the decision to retire from gymnastics.

\section{Injury Risk Factors}

An important part of gymnastics injury epidemiology is the identification and analysis of factors that contribute to the occurrence of gymnastics injury. 
These factors (i.e., the why) are commonly referred to as risk factors and may be classified as either intrinsic or extrinsic. Intrinsic factors are individual biological and psychosocial characteristics predisposing a gymnast to the outcome of injury. Extrinsic risk factors are factors that have an impact on the gymnast while she is participating in her sport, for example training methods or equipment.

Results of gymnastics risk factor studies are summarized in table 9 and discussed below with reference to intrinsic or extrinsic factors $[3,4,9,12,13$, $17,23,80-83]$. The information provided should be interpreted cautiously due to the methodological problems and study differences described earlier. Further, risk factors may interact differently with the categories of injury onset, a possibility which was not accounted for in most of the studies reviewed. The risk factors identified should be viewed as initial steps in the important search for predictor variables and may provide interesting characteristics for manipulation in other experimental designs.

\section{Intrinsic Factors}

Physical Characteristics

Analytical cohort studies indicate that in comparison with uninjured or low-injury-risk gymnasts, the injured or high-injury-risk gymnasts are characterized by greater body size (height and weight), age, and body fat [80-82]. In one of these studies [80], however, measurements were taken after injury occurred, thus invoking the possibility that an injury itself caused the observed difference. Additionally, exposure patterns in injured and uninjured gymnasts were not identified as a basis for determining reasons for injury occurrence.

It is possible that factors such as greater height, weight and age tend to characterize older gymnasts with more years training and involvement in higher levels of training and competition. Older gymnasts may be more likely to sustain injury because of more complex and difficult skills and greater accumulated exposure to training.

There are some data which suggest that somatotype may relate to risk of injury. One study [80] reported mesomorphy to be negatively related to injury. However, as mentioned previously, these analyses were based on the injury data obtained retrospectively (before injury occurred). Additionally, comparing only one somatotype component may give a misleading interpretation of the role of overall somtatotype, as the relative dominance of components may vary from one gymnast to another. Nonetheless, it seems reasonable to expect that gymnasts characterized by a somatotype most congruent to the physical demands of their sport would also be most protected from injury. Notably, Caine et al. [13] reported that gymnasts who lost the most time from training due to injury were also characterized by body types which were least typical of female gymnasts. 
Table 9. A comparision of results arising from analytical cohort studies (adapted from Caine [2] and Caine et al. [27])

\begin{tabular}{|c|c|c|c|c|c|c|}
\hline Study & Duration & Design & Method & $\mathrm{n}$ & Purpose & Results \\
\hline \multirow[t]{2}{*}{$\begin{array}{l}\text { Steele and } \\
\text { White [80] }\end{array}$} & 2 years & retrospective & questionnaire & $40 \mathrm{~F}$ & $\begin{array}{l}\text { To determine whether } \\
\text { high and low injury } \\
\text { groups could be } \\
\text { identified }\end{array}$ & $\begin{array}{ll}\text { High and low injury } & \\
\text { risk gymnasts could } & \\
\text { be classified with } 70 \% \text { and } \\
79 \% \text { accuracy, respectively; } \\
\text { significant differences } \\
\text { ( p <0.05 or better) } & \\
\text { were found in the } & \\
\text { following variables: } & \\
\text { weight } & \text { high }>\text { low } \\
\text { height } & \text { high }>\text { low } \\
\text { age } & \text { high }>\text { low } \\
\text { mesomorphy } & \text { high }>\text { low } \\
\text { quetelet index } & \text { high }<\text { low } \\
\text { shoulder flexion } & \text { high }>\text { low } \\
\text { lumbar extension } & \text { high }\end{array}$ \\
\hline & & & & & $\begin{array}{l}\text { To identify injury } \\
\text { predictors }\end{array}$ & $\begin{array}{l}\text { Variables associated with } \\
\text { injury risk }(\mathrm{p}<0.05 \text { or better }) \text { : } \\
\text { weight }(+), \text { mesomorphy }(-), \\
\text { lumbar curvature }(+), \\
\text { age }(+), \text { and height }(-)\end{array}$ \\
\hline $\begin{array}{l}\text { Kerr and } \\
\text { Minden [23] }\end{array}$ & 2 years & retrospective & questionnaire & $41 \mathrm{~F}$ & $\begin{array}{l}\text { To determine whether } \\
\text { selected psychological } \\
\text { variables (trait anxiety } \\
\text { locus of control, self- } \\
\text { concept, and stressful } \\
\text { life events) were related } \\
\text { to the number and } \\
\text { severity of injuries }\end{array}$ & $\begin{array}{l}\text { Moderately strong } \\
\text { relationship between } \\
\text { stressful life events and } \\
\text { injury number }(r=0.53 \\
\mathrm{p}<0.01) \text { and between } \\
\text { stressful life events and } \\
\text { injury severity }(\mathrm{r}=0.53 \\
\mathrm{p}<0.01)\end{array}$ \\
\hline
\end{tabular}


Pettrone and Ricciardelli [3]

Caine et al. [13]
7 months

prospective

(n)

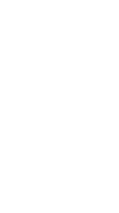

1 year prospective interview
5

F To identify physical parameters which predispose the athlete to injury

To determine the extent to which group classification into high and low injury risk groups could be predicted
Duration and frequency of workouts in clubs with high injury rates were significantly greater $(\mathrm{p}<0.05)$ than in clubs with low injury rates (20-30 hours/ week vs. 4-6hours/week)

No significant canonical relationship between the limited selection of predictor variables and the injury measures $(\mathrm{p}=0.11)$; separate muliple regression tests $(\mathrm{p}<0.05)$ showed maturation rate associated with injury rate $(+)$ and competitive level associated with time loss $(+)$

The results of discriminant analysis involving the criterion variable injury rate were not significant $(\mathrm{p}=0.10)$; for the criterion variable individual proportion time loss, the groups were significantly different $(\mathrm{p}<0.05)$ and could best be distinguished as a result of the contribution of competitive level (high $>$ low) and 
Table 9 (continued)

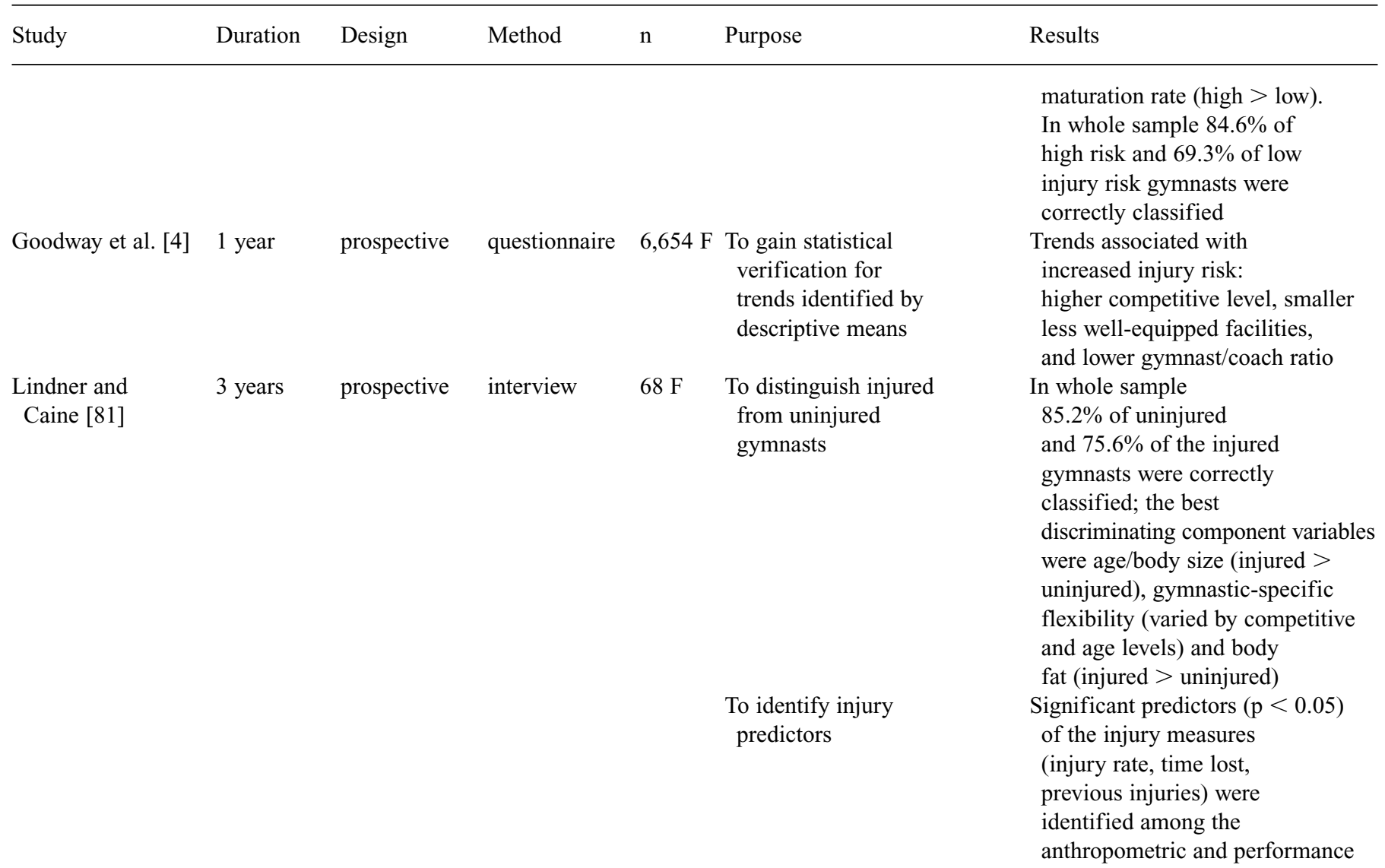


Lindner and

Caine [82]

Kolt and

Kirkby [17]
$162 \mathrm{~F}$

\section{To determine the number, site, and type of injury}

Incurred by elite and sub-elite female competitive gymnasts

Kolt and Kirkby [83]
12 months retrospective questionnaire
To assess the role of life stress, competitive anxiety, self esteem, and locus of control in injury components, but were specific to the components and various age and competitive levels.

Overall, training

hours/week was a positive predictor of time lost $(\mathrm{p}<0.01)$

In whole sample, $80 \%$

of low level and $100 \%$

of high level gymnasts were correctly classified; time loss due to injury $(\mathrm{p}<0.001)$ and number of previous injuries were greater $(\mathrm{p}<0.05)$ for high level gymnasts

Injury rate for elite gymnasts (per 1,000 h) was lower than sub-eltie gymnasts $(\mathrm{p}=0.03)$

Distribution of injuries was significantly different $(p=0.001)$ with a higher proportion of elite gymnasts reporting tendonitis and growth plate injuries

Life stress was a significant predictor of injury for the overall sample and for the nonelite gymnasts 
Table 9 (continued)

\begin{tabular}{|c|c|c|c|c|c|c|}
\hline Study & Duration & Design & Method & $\mathrm{n}$ & Purpose & Results \\
\hline $\begin{array}{l}\text { Kolt and } \\
\text { Kirkby [12] }\end{array}$ & 18 months & prospective & questionnaire & $64 \mathrm{~F}$ & $\begin{array}{l}\text { To compare injury rates } \\
\text { in elite and sub-elite } \\
\text { gymnasts }\end{array}$ & $\begin{array}{l}\text { Rates per } 1,000 \mathrm{~h} \text { training } \\
\text { were lower for elite than } \\
\text { sub-elite gymnasts }(\mathrm{p}=0.01)\end{array}$ \\
\hline Caine et al. [9] & 3 years & prospective & interview & $79 \mathrm{~F}$ & $\begin{array}{l}\text { To estimate the relative } \\
\text { risk of injury in competition } \\
\text { versus training among } \\
\text { beginning and advanced } \\
\text { gymnasts }\end{array}$ & $\begin{array}{l}\text { The RR of injury } \\
\text { during competition relative } \\
\text { to practice was } 2.69 \\
(95 \% \mathrm{CI}: 1.53,4.75 \text {; } \\
\mathrm{p}<0.001) \text {. The relative RR } \\
\text { during competition was } 0.47 \\
\text { for beginners ( } 95 \% \mathrm{CI}: 0.07,3.42) \\
\text { and } 4.34 \text { for advanced } \\
\text { gymnasts }(95 \% \mathrm{CI}: 2.39,7.88 ; \\
\mathrm{p}=0.035)\end{array}$ \\
\hline DiFiori et al. [60] & 1 year & prospective & interview & $\begin{array}{l}21 \mathrm{~F} \\
26 \mathrm{M}\end{array}$ & $\begin{array}{l}\text { To determine the prevalence } \\
\text { and characteristics of wrist } \\
\text { pain among young, nonelite } \\
\text { gymnasts }\end{array}$ & $\begin{array}{l}\text { Multivariate analysis } \\
\text { revealed that adolescent } \\
\text { gymnasts between } 10 \text { and } \\
14 \text { years of age were } \\
\text { significantly more likely } \\
\text { to report wrist pain than those } \\
\text { who were either above or below } \\
\text { this age range ( } \mathrm{p}=0.03) \\
\text { either above or below this age } \\
\text { range }(\mathrm{p}=0.03)\end{array}$ \\
\hline
\end{tabular}


It is believed that the growth spurt is associated with an increased risk of injury [84-86]. Caine et al. [13] reported that injury rate was almost twice as great for female gymnasts experiencing rapid compared to stable growth (as indicated by Tanner stages), regardless of competitive level. Similarly, DiFiori et al. [60] reported that male and female gymnasts between 10 and 14 years of age were significantly more likely to report wrist pain than those who were either above or below this age range. However, these findings await confirmation from an analysis of individual longitudinal growth records and injury rates.

\section{Motor Characteristics}

One study [81] reported speed (-), balance $(-)$, endurance $(+)$ and flexibility $(+)$ as significant injury predictors among club-level female gymnasts; however, these were not significant at all age and competitive levels studied. Additionally, the number of gymnasts in each age and competitive level were small thus limiting the precision of analysis within subgroups.

One study [80] reported that the high injury risk was associated with a relatively low shoulder flexion and high lumbar extension. Once again, these measures were taken after the injury occurred, thus the possibility that the injury itself caused the observed difference. In addition, as mentioned above, exposure patterns in injured and uninjured gymnasts were not identified as a basis for determining reasons for injury occurrence. No doubt success in gymnastics depends on a certain minimum of joint looseness, yet flexibility is specifically difficult to define and its relationship to injury remains conjectural.

\section{Psychosocial Characteristics}

An intriguing, but relatively unexplored area of injury research in gymnastics, is the role of psychosocial factors in injury occurrence. In one study [23], a moderately strong positive relationship between the number of stressful life events and injury number and severity was reported. In a more recent study [83], life stress was a significant predictor of injury in elite and nonelite competitive female gymnasts who completed a questionnaire covering personal, training, and injury data. In both of these studies, however, the psychosocial measures were taken after the injury occurred, thus invoking the possibility that the stress profiles of the gymnasts were different at the time of injury.

\section{Extrinsic Factors}

Exposure

The results of analytical studies are inconclusive as to whether injury rates are greatest at advancing levels of training and competition [9, 12, 13, 17]. Two studies report significantly lower injury rates in elite compared to sub-elite 
gymnasts $[12,17]$. In contrast, when proportion time loss and injury rate were used as criterion variables [13], the analysis resulted in a significant effect and competitive level surfaced as best discriminator between high and low injury risk gymnasts. In a recent study [9], the relative risk for injury among advanced gymnasts was 1.47 times greater than a beginning group. When the advanced group was divided into training versus competition time, the RR of injury compared to the beginning group was not inflated in training $(R R=0.97)$ while it is much higher during competition $(\mathrm{RR}=4.22)$.

\section{Suggestions for Injury Prevention}

The aim of this overview of the gymnastics injury literature was to provide epidemiological information that would be useful to minimize injury morbidity and prevent injury to young athletes through an understanding of how, where, and why injuries occur in the sport. Arising from this integrative review of the gymnastics injury literature are the following injury patterns:

- higher rates of injuries among advanced-level gymnasts in some studies $[7,9,13,22]$;

- the most frequently injured body parts: shoulder, wrist, elbow, lower back, ankle and knee $[6,7,9,11,13,16,18,25]$;

- higher rates of injures in competition, especially among advanced-level gymnasts [9];

- floor exercise is characterized by the highest rate of injury [9];

- most injuries are acute [3, 4, 7, 9-12, 14, 17, 21, 22, 27]; however, there is some evidence that advanced-level or heavily trained gymnasts incur more overuse conditions than their less-advanced peers [12, 13, 17];

- national level gymnasts incur relatively high rates of injury associated with competitions; the most frequently treated injury conditions at these competitions were sprains, overuse injuries and nonspecific pain and common injury locations were the ankle, low back, and lower leg [unpubl. data];

- a relatively high frequency of injury during the early part of practice or during timed warmup for competition $[9,10,13]$;

- increased rates of injury following periods of reduced training, during competitive routine preparation, and during the weeks just prior to competition $[9,13,23]$;

- $\quad$ sprains and strains are the most common injury types $[3,5,6,9,10,12$, 13, 17];

- a high prevalence of overuse injuries affecting the spine and wrist of both male and female gymnasts [33-63]; 
- catastrophic injuries appear to be infrequent outcomes of high school gymnastics participation $[69,70]$; however, there are no rate data on this injury type among club-level gymnasts;

- time loss associated with injury is greater for competition than for practice injuries, and greater for advanced- than beginning-level gymnasts $[9,12$, $13,17]$

- about one in four injuries is a re-injury $[9,10,13]$; there is some evidence that most re-injuries are chronic injuries $[9,13]$;

- little is known about the long-term effect of gymnastics injuries; however, there is evidence that history of back and elbow injury is related to persistence of symptoms following retirement [74-76];

- injury is a reason for dropping out for some gymnasts, perhaps as many as one in ten $[9,13,16,18]$; and

- factors shown to be associated with increased risk of injury include: greater body size, age, and body fat [80-82]; periods of rapid growth [13, $60]$; life stress $[23,83]$; and, in some studies, advanced levels of training and competition $[9,13]$.

Suggested preventive measures arising from the studies reviewed in this chapter are listed in table 10 according to study design. Recommendations are referenced to indicate source and any available supporting evidence. As indicated in the table, most of the suggestions were derived from descriptive data and await confirmation from more controlled epidemiological study, including evaluation for their effectiveness in preventing injuries.

In closing, it is important to emphasize that the prevention of gymnastics injury is a complex phenomenon which requires interaction among gymnast, coach, gymnastics governing body and medical support staff. A multidisciplinary team including coach, athletic trainer, psychologist and physician is essential to optimizing the preventive strategies.

\section{Suggestions for Future Research}

An important purpose of this chapter has been to identify methodological weaknesses in the literature and provide suggestions for further research. This is an integral component of the 'epidemiology of gymnastics injuries' because informed decisions related to the establishment of injury prevention programs depend on accurate and reliable data. Above all, this overview of the gymnastics injury literature underscores the need to establish national injury surveillance systems designed to provide current and reliable data on injury trends in boys and girls club-level gymnastics. 
Table 10. Suggestions for injury prevention (adapted from Caine [2])

Cross-sectional Cohort

Coaching-Education

Require coaches to meet a minimum level of qualification

On the importane of protecting gymnasts from premature

attempts to execute advanced maneuvers

Coaching - Physical Preparation

Provide specific stretching and strengthening exercises - particularly

for the Achilles tendon, hamstring and quadriceps muscles

Maximal conditioning of those muscles used for spinal and abdominal strengthening to avoid chronic back conditions

Conditioning programs to prevent muscle strains associated with the short bursts of running in floor exercise and vaulting

Coach should not emphasize gymnastics-specific flexibility (splits,

leg raises) before extent flexibility at various joints is adequately developed Encourage wrist strengthening and flexibility exercises to help protect the wrist against chronic injury

Teach and practice correct landing techniques to prevent fractures and dislocations of the upper extremity

Ensure adequate warmup

Recognize the existence or potential for growth plate injury and the importance of referring the gymnast for medical evaluation as soon as symptoms occur Pain is a signal in an important process and should be regarded as a

warning, not something to get used to; 'no pain - no gain' is inappropriate
Weiker [7]

Clarke [69]

Mackie and Taunton [22]

Soler and Calderon [44] Garrick and Requa [6]

Garrick and Requa [6]

Lindner and Caine [10]

Caine et al. [52]

Mackie and Taunton [22]

Caine et al. [13];

Pettone and Riccardelli [3]

Caine et al. [52]

Kolt and Kirkby $[12,17]$

Jackson et al. [34];

Caine et al. [34]
Caine et al. [13] 
Conditioning specifically designed to 'smooth the transition' from skill training to routine training (e.g., ergometer interval training, anaerobic conditioning, and weight training)

Ensure the technically correct performance of movements to avoid unnecessary overloading of the spine

\section{Coaching - Training}

Alternate loading types during workouts; for example alternate swinging and support movements so as to reduce stress on the wrist

Train gymnasts in a cyclically progressive manner so that the [3]

gymnastis not increasing the dose of load bearing in a progressive stepwise fashion but rather in a cyclical manner; every escalation is followed by a decrease in overall load for a week's time, followed by another increase, thereby allowing reparative time for connective tissue structures

Reduce duration of rotations and increase their number per workout to avoid lack of concentration and inattentiveness; avoid training when concentration is poor

Reduce training loads during periods of rapid growth

Avoid conditions in which the gymnast is allowed merely to go through the motions of a skill without a specific assignment requiring the gymnast's attention

Spotting should be used more extensively during practice and obligatory during high-risk events

Availability of well-trained spotters
Caine et al. [52]

Soler and

Calderson [44]

Caine et al. [52]

Caine et al. [52]

Pettrone and Riccardelli

Lindner and Caine [10]; Mackie and Taunton [22]

Caine et al. [52];

DeFiori et al. [55]*
Caine et al. [13]:*

Lindner and Caine $[81]^{*}$

DiFiori et al. [60]

Lindner and Caine [10]

Bak et al. [11];

Weiker [7] 
Table 10 (continued)

Preventive measures

Preventive measures

\section{Equipment}

Encourage use of personal protective equipment (e.g., dowel grips, handguards)

Increase thickness of landing mats during practice and competition Re-evaluation of the criteria of the scoring system for competition

\section{Health Support System - Screening}

Administer a preparticipation physical examination (PPE) to each gymnast prior to entry into competitive gymnastics, before any change in the competitive level, and before returning to practice following injury

Biannual musculoskeletal screening and, when indicated, AP radiographs of the wrist to rule out stress changes of the growth plate

Periodic physical examination focusing on epiphyseal areas of growing gymnasts such that injuries to these areas can be diagnosed at an early stage and modifications made to the training program to assist in the recovery process

\section{Health Support System - Treatment and Rehabilitation}

The physician should heighten awareness and encourage extra vigilance on the part of coaches during the period of routine preparation and competition given the increased rate of injury during these periods Gymnastic clubs include within their cost structure sufficient funds
Type of evidence

Cross-sectional Cohort

Caine et al. [52]

Goldstein et al. [42]

Bak et al. [11]

Soler and Calderson [44] Kolt and Kirkby [12,17];

Caine et al. [13]

Steele and White $[80]^{*}$

Kolt and Kirkby [12,17]

Caine et al. [9]

Caine et al. [52]

Jackson et al. [34];

Kolt and Kirkby [12];

Garrick and Requa [6]; 
The functions of this individual should include the following:

Caine et al. [9]

- early detection of developing stress injuries

Caine et al. [9]

- identify potential injury-provoking practices

- liaison between gymnasts, coaches, and physician

- oversee the development of special rehabilition programs for injured gymnasts identified in the PPE

Teatment of chronic injuries before they become disabling

Steele and White $[80]^{*}$

The Sport

Re-evaluation of competition rules and the performance environment given the high incidence of injury linked with competition

Caine et al. [9]

*Derived from an analytical study. 
In particular, injury surveillance systems could provide the needed and on-going descriptive data related to important epidemiological 'targets' or areas that merit closer scrutiny. Targets for further study identified in this literature review include the following:

- injuries that cause restriction or loss of participation for extended periods of time (e.g., $>7$ days);

- injuries that require surgery or are otherwise severe in nature (e.g., concussions);

- injuries that are catastrophic;

- re-injuries;

- injuries that may affect skeletal growth;

- injuries that occur during or following warm-up;

- injuries that occur in the weeks just prior to competition;

- injuries that occur during competition; and

- long-term follow-up of gymnastics injuries.

In addition to injury surveillance systems, in-depth epidemiological studies are needed. A critical aspect of the proposed research is the precise determination of exposure patterns in injured and uninjured gymnasts as a basis for determining reasons for injury occurrence. As this review of the gymnastics injury literature has shown, few injury risk factors have been subjected to statistical tests for correlation or evaluated for predictive value. And there have been no studies published that were designed to determine the effectiveness of specific injury prevention measures. Although the institution of a preventive strategy on the basis of clinical practice or descriptive epidemiological data may still prevent injury, the most reliable suggestions for injury prevention are believed to emerge from experimental or quasiexperimental research [9].

Examples of questions or issues that have arisen from this review of the gymnastics injury literature and which may help direct further analytical research initiatives include the following: Why is the risk of injury in competition so much higher than training, especially among advanced-level gymnasts? Do some psychosocial factors increase the risk of competition injury and can these factors be controlled or eliminated? Can an increased risk of injury during periods of rapid growth be confirmed with reference to growth velocity data? If so, what can be done to reduce this increased risk of injury? What is the relationship between poor technique and risk of injury? What factors are associated with increased risk of the nagging chronic injuries experienced by gymnasts? Can these factors be controlled or eliminated? What are the longterm effects of gymnastics injuries? And, would a well-designed pre-season conditioning and proprioceptive balance training program help to reduce the risk of lower extremity injuries? 
In closing, it is important to stress that it is only through concerted collaborative efforts that optimal results could be achieved. The research team should include the coach, athletic trainer, physician, and epidemiologist who interact in a very dynamic and fluid manner. In addition, it is important to emphasize that every effort should be made by the research team to establish an open and trusting dialogue with gymnasts and their parents. Only when this could be achieved, could an adequate database be established.

\section{References}

1 Sands W: Injury prevention in women's gymnastics. Sports Med 2000;30:359-373.

2 Caine DJ: Injury epidemiology; in Sands WA, Caine DJ, Borms J (eds): Scientific Aspects of Women's Gymnastics. Med Sport Sci. Basel, Karger, 2003, vol 45, pp 72-109.

3 Pettrone FA, Ricciardelli E: Gymnastic injuries: The Virginia experience 1982-83. Am J Sports Med 1987;15:59-62.

4 Goodway JD, McNaught-Davis JP, White J: The distribution of injuries among young female gymnasts in relation to selected training and environmental factors; in Beunen G (ed): Children and Exercise XIV. Band 4. Schriftenreihe der Hamburg-Mannheimer-Stiftung fur Informationsmedizeft Enke Verlag, 1989.

5 Lowry CB, Leveau BF: A retrospective study of gymnastic injuries to competitors and noncompetitors in private clubs. Am J Sports Med 1982;10:237-239.

6 Garrick JG, Requa RK: Epidemiology of women's gymnastics injuries. Am J Sports Med 1980;8:261-264.

7 Weiker GG: Injuries in club gymnastics. Phys Sportsmed 1985;13:63-66.

8 Vergouwen P: Epidemiologie van blessures bij topturnsters. Geneeskd Sport 1986;18:27-33.

9 Caine D, Knutzen K, Howe W, Keeler L, Sheppard L, Henrichs D, Fast J: A three-year epidemiological study of injuries affecting young female gymnasts. Phys Therap Sport 2003;4:10-23.

10 Lindner KJ, Caine D: Injury patterns of female competitive club gymnasts. Can J Sport Sci 1990;15:254-261.

11 Bak K, Kalms SB, Olesen J, Jurgensen U: Epidemiology of injuries in gymnastics. Scand J Med Sci Sports 1994;4:148-154.

12 Kolt GS, Kirkby RJ: Epidemiology of injury in elite and subelite female gymnasts: A comparison of retrospective and prospective findings. Br J Sports Med 1999;33:312-316.

13 Caine D, Cochrane B, Caine C, Zemper E: An epidemiological investigation of injuries affecting young competitive female gymnasts. Am J Sports Med 1989;17:811-820.

14 Steele VA, White JA: Injury amongst female gymnasts. Proceedings of the Society of Sports Sciences: Sport and Science Conference. Liverpool, School of Physical Education and Recreation, 1983.

15 Backx FJG, Beijer HJM, Bol E, Erick WBM: Injuries in high-risk persons and high-risk sports. A longitudinal study of 1818 school children. Am J Sports Med 1991;19:124-130.

16 Dixon M, Fricker P: Injuries to elite gymnasts over 10 yr. Med Sci Sports Exerc 1993;25: $1322-1329$.

17 Kolt GS, Kirkby RJ: Epidemiology of injuries in Australian female gymnasts. Sport Med Train Rehab 1995;6:223-231.

18 Kerr GA: Injuries in artistic gymnastics. J Cdn Athlet Therap Assoc 1991;April:19-21.

19 McLain LG, Reynolds S: Sports injuries in a high school. Pediatrics 1989;84:446-450.

20 NCAA Injury Surveillance System (ISS). NCAA Online. http://www.ncaa.org/sports_science/ injury_surveillance.

21 Jones A: Training of Young Athletes Study. London, The Sports Council, 1992.

22 Mackie SJ, Taunton JE: Injuries in female gymnasts. Trends suggest prevention tactics. Phys Sportsmed 1994;22:40-45. 
Kerr GA, Minden H: Psychological factors related to the occurrence of athletic injuries. J Sport Exer Psych 1988;10:167-173.

24 Homer S, Mackintosh S: Injuries in young female elite gymnasts. Physiotherapy 1992;78: 804-808.

25 Lueken J, Stone J, Wallach BA: Olympic training center report men's gymnastics injuries. Gymnastics Safety Update 1993;8:4-5.

26 Sands WA, Shultz BB, Newman AP: Women's gymnastics injuries. A 5-year study. Am J Sports Med 1993;21:271-276.

27 Caine D, Lindner K, Mandelbaum B, Sands W: Gymnastics; in Caine D, Caine C, Lindner K (eds): Epidemiology of Sports Injuries. Champaign, Human Kinetics, 1996.

28 Leglise M: Limits on young gymnast's involvement in high-level sport. Technique 1998;18:8-14.

29 Sands WA, Newman AP, Harner C, Paulos LE: A two year study of injury in collegiate women's gymnastics. Technique 1987;7:4-10.

30 Walsh MW, Huurman WW, Shelton GL: Overuse injuries of the knee and spine in girl's gymnastics. Clin Sports Med 1984;3:829-850.

31 Bruggemann GP: Mechanical load in artistic gymnastics and its relation to apparatus and performance; in Leglise M (ed): Symposium Medico-Technique 1999. Lyss (Switzerland), International Gymnastics Federation, pp 17-27.

32 Hall SJ: Mechanical contribution to lumbar stress injuries in female gymnasts. Med Sci Sports Exerc 1986;18:599-602.

33 Swärd L: The thoracolumbar spine in young elite athletes. Current concepts on the effects of physical training. Sports Med 1992;13:357-362.

34 Jackson DW, Wiltse LL, Cirincione RJ: Spondylolysis in the female gymnast. Clin Orthop 1976;117:68-73.

35 Rossi F: Spondylolysis, spondylolisthesis and sports. J Sports Med 1978;18:317-340.

36 Ohlen G, Wredmark T, Spangfort E: Spinal sagittal configuration and mobility related to low-back pain in the female gymnasts. Spine 1989;14:847-850.

37 Sward L, Hellstrom M, Jacobsson B, Peterson L: Spondylolysis and the sacro-horizontal angle in athletes. Acta Radiol 1989;30:359-364.

38 Rossi F, Dragoni S: Lumbar spondylolysis: Occurrence in competitive athletes. J Sports Med Phys Fitness 1990;30:450-452.

39 Tertti M, Paajanen H, Kujula UM, Alanen A, Salmi TT, Kormano M: Disc degeneration in young gymnasts. A magnetic resonance imaging study. Am J Sports Med 1990;18:206-208.

40 Hellström M, Jacobsson B, Swärd L, Peterson L: Radiologic abnormalities of the thoraco-lumbar spine in athletes. Acta Radiol 1990;31:127-132.

41 Swärd L, Hellstrom M, Jacobsson B, Peterson L: Back pain and radiologic changes in the thoracolumbar spine of athletes. Spine 1990;15:124-129.

42 Goldstein JD, Berger PE, Windler GE, Jackson DW: Spine injuries in gymnasts and swimmers: An epidemiologic investigation. Am J Sports Med 1991;19:463-468.

43 Sward L, Hellstrom M, Jacobsson B, Karlsson L: Vertebral ring apophysis injury in athletes. Is the etiology different in the thoracic and lumbar spine? Am J Sports Med 1993;21:841-845.

44 Soler T, Calderon C: The prevalence of spondylolysis in the Spanish elite athlete. Am J Sports Med 2000;28:57-62.

45 Szot Z, Boron Z, Galaj Z: Overloading changes in the motor system occurring in elite gymnasts. Int J Sports Med 1985;6:36-40.

46 Sward L, Hellstrom M, Jacobsson B, Nyman R, Peterson L: Disc degeneration and associated abnormalities of the spine in elite gymnasts. Spine 1991;16:437-443.

47 Dzioba RB: Gymnastics; in Schneider RC, Kennedy JC, Plant ML (eds): Sports Injuries. Mechanisms, Prevention, and Treatment. Baltimore, Williams and Wilkins, 1985, pp 139-162.

48 Greene TL, Hensinger RN, Hunter LY: Back pain and vertebral changes simulating Scheuermann's disease. J Ped Orthop 1985;5:1-7.

49 Swärd L, Hellstrom M, Jacobsson B, Nyman R, Peterson L: Acute injury of the vertebral ring apophysis and intervertebral disc in adolescent gymnasts. Spine 1990;15:144-148.

50 Katz DA, Scerpella TA: Anterior and middle column thoroclumbar spine injuries in young female gymnasts. Report of seven cases and a review of the literature. AJSM 2003;31:611-616. 
51 Bennett DL, Nassar L, DeLano M: Lumbar spine MRI in the in the elite level gymnast. Paper presented at the 2003 USA Gymnastics National Congress: Science in Gymnastics Symposium, Anaheim, CA, August 23, 2003.

52 Caine D, Roy S, Singer K, Broekhoff J: Stress changes of the distal radial growth plate. A radiographic survey of 60 young competitive gymnasts and an epidemiologic review of the related literature. Am J Sports Med 1992;20:290-298.

53 DeFiori JP, Mandelbaum BR: Factors associated with wrist pain in the young gymnast. Am J Sports Med 1996;24:9-14.

54 DeFiori JP, Puffer JC, Mandelbaum BR, Dorey F: Distal radial growth plate injury and positive ulnar variance in nonelite gymnasts. Am J Sports Med 1997;25:763-768.

55 DeFiori JP, Puffer JC, Aish B, Dorey F: Wrist pain, distal radial physeal injury and ulnar variance in young gymnasts: Does a relationship exist? Am J Sports Med 2002;30:879-885.

56 Auberge T, Zenny JC, Duvallet A, Godefroy D, Horreard P, Chevrot A: Study of bone maturation and osteo-articular lesions in top level sportsmen: A review of 105 cases. J Radiol (Paris) 1984;65:555-561.

57 Roy S, Caine D, Singer K: Stress changes of the distal radial epiphysis in young gymnasts. A report of twenty-one cases and a review of the literature. Am J Sports Med 1985;13:301-308.

58 DeSmet L, Claessons A, Lefevre J, DeCorte F, Beunen G, Stijnen V, Maes H, Veer FM: Gymnast wrist: An epidemiological survey of the ulnar variance in elite female gymnasts. Am J Sports Med 1994;22:846-850.

59 Chang CY, Shih C, Penn IW, Shih CM, Chang T, Wu JJ: Wrist injuries in adolescent gymnasts of a Chinese opera school: Radiographic survey. Radiology 1995;195:861-864.

60 DiFiori JP, Puffer JC, Aish B, Dorey F: Wrist pain in young gymnasts: Frequency and effects upon training over 1 year. Clin J Sport Med 2002;12:348-353.

61 Caine D, Howe W, Ross W, Bergman G: Does repetitive physical loading inhibit radial growth in female gymnasts? Clin J Sport Med 1997;7:302-308.

62 Albanese SA, Palmer AK, Kerr DR, Carpenter CW, Lisi D, Levinsohn EM: Wrist pain and distal growth plate closure of the radius in gymnasts. J Ped Orthop 1989;9:23-28.

63 Howe W, Caine D, Keeler L, Bergman G: Wrist Pain - Gymnastics. Med Sci Sports Exerc 1997; 29:S151.

64 Nattiv A, Mandelbaum BR: Injuries and special concerns in female gymnasts. Detecting, treating, and preventing common problems. Phys Sportsmed 1993;21:66-82.

65 Bak K, Boeckstyns M: Epiphysiodesis for bilateral irregular closure of the distal radial physis in a gymnast. Scand J Med Sci Sports 1997;7:363-366.

66 Lishen Q, Jianhua O: Epiphyseal injury in gymnasts. Chinese J Sports Med 1983;2:7-12.

67 Westly M: A gymnast's long fall. A minor misstep leaves China's best vaulter paralyzed. Can new drugs help her to walk again? Newsweek, August 3, p 56.

68 Ryan J: Pretty Girls in Little Boxes: The Making and Breaking of Elite Gymnasts and Figure Skaters. New York, Doubleday, 1995.

69 Clarke KS: A survey of sports-related spinal cord injuries in schools and colleges, 1973-1975. J Safety Res 1977;9:140-146.

70 National Center for Catastrophic Sports Injury Research. Available from URL: http:// www.unc.edu/depts/nccsi/ (accessed July 30, 2004).

71 Katoh S, Shigu H, Itaka T, Iwatsubo E: Sports-related spinal cord injury in Japan. Spinal Cord 1996;34:416-421.

72 Schmitt H, Gerner JH: Paralysis from sport and diving accidents. Clin J Sport Med 2001; $11: 17-22$.

73 Thompson N, Halpern B, Curl WW, Andrews JR, Hunter SC, McLeod WD: High school football injuries: Evaluation. Am J Sports Med 1987;15:117-124.

74 Lundin O, Hellstrom M, Nilsson I, Sward L: Back pain and radiological changes in the thoracolumbar spine of athletes. A long-term follow-up. Scand J Med Sci Sports 2001;11:103-109.

75 Tsai L, Wredmark T: Spinal posture, sagittal mobility, and subjective rating of back problems in former female elite gymnasts. Spine 1993;18:872-875.

76 Maffuli N, Chan D, Aldridge MJ: Derangement of the articular surfaces of the elbow in young gymnasts. J Ped Orthop 1992;12:344-350. 
77 Singer KM, Roy SP: Osteochondrosis of the humeral capitellum. Am J Sports Med 1984;12: 351-360.

78 Jackson DW, Silvino N, Reiman P: Osteochondritis in the female gymnast's elbow. Arthroscopy 1989;5:129-136.

79 Lindholm C, Hagenfeldt K, Ringertz BM: Pubertal development in elite juvenile gymnasts. Effects of physical training. Acta Obstet Gynecol Scand 1994;73:269-273.

80 Steele VA, White JA: Injury prediction in female gymnasts. Br J Sports Med 1986;20:31-33.

81 Lindner KJ, Caine D: Injury predictors among female gymnasts' anthropometric and performance characteristics; in Hermans GP, Mosterd WL (eds): Sports, Medicine and Health. Amsterdam, Excerpta Medica, 1990, pp 136-141.

82 Lindner KJ, Caine D: Physical and performance characteristics of injured and injury-free female gymnasts. J Hum Mov Stud 1993;25:69-83.

83 Kolt G, Kirkby R: Injury in Australian competitive gymnasts: A psychological perspective. Aust J Physiother 1996;42:121-126.

84 Micheli LJ: Overuse injuries in children's sports: The growth factor. Orthop Clin North Am 1983;14:337-360.

85 Bailey DA, Wedge JH, McCulloch RG, Martin AD, Bernardson SC: Epidemiology of fractures of the distal end of the radius in children as associated with growth. J Bone Jt Surg 1989;71A: 1225-1231.

86 Caine D, Lindner K: Overuse injuries of growing bones: The young female gymnast at risk. Phys Sportsmed 1985;13:51-62.

Prof. Dennis Caine, PhD

Department of Physical Education, Health and Recreation

Western Washington University

Bellingham, WA 98225-9067 (USA)

Tel. +1 36065035 29, Fax +1 36065074 47, E-Mail Dennis.Caine@wwu.edu 